\title{
Short-Term Antibacterial Efficacy of Three Bioceramic Root Canal Sealers Against Enterococcus Faecalis Biofilms
}

\section{Antibakterijska učinkovitost triju biokeramičkih materijala za punjenje korijenskih kanala na biofilm s bakterijom Enteroccocus faecalis}

\author{
${ }^{1}$ Department of Endodontics and Restorative Dentistry, Dental polyclinic Split, Croatia \\ Odjel za endodonciju i restaurativnu stomatologiju Stomatološke poliklinike Split, Hrvatska \\ 2 Department of Clinical and Molecular Microbiology, Clinical Hospital Centre Zagreb, Croatia \\ Zavod za kliničku i molekularnu mikrobiologiju KBC-a Zagreb, Hrvatska \\ ${ }^{3}$ Department of Materials, Faculty of Engineering and Naval Architecture, University of Zagreb, Croatia \\ Zavod za materijale Fakulteta strojarstva i brodogradnje Sveučilišta u Zagrebu, Hrvatska \\ ${ }^{4}$ Department of Endodontics and Restorative Dentistry, School of Dental Medicine, University of Zagreb, Croatia \\ Zavod za endodonciju i restaurativnu stomatologiju Stomatološkog fakulteta Sveučilišta u Zagrebu, Hrvatska
}

\begin{abstract}
Objectives: The aim of the study was to evaluate the antimicrobial efficacy of three bioceramic root canal sealers against Enterococcus faecalis (E. faecalis) biofilm. Material and methods: $E$. faecalis bacterial suspension was grown on filter paper discs on agar plates. After the incubation period, the discs were covered with four different root canal sealers: 1) Premixing bioceramic root canal sealer (TotalFill BC Sealer); 2) Dual component bioceramic sealer (BioRoot RCS); 3) Mineral trioxide agreggate based sealer (MTA Fillapex); 4) Epoxy resin-based selar (AH Plus). After contact time of 60 minutes, the sealers were removed, and the discs were transferred into sterile tubes containing phosphate buffered saline. After serial dilutions, the aliquots of the suspension were cultivated for 24 hours. After the incubation period, the colony forming units (CFUs) were counted. Results: There were no significant differences in antibacterial efficacy between the Total Fill BC Sealer and the AH Plus sealer $(p=0.386)$. Both sealers showed better antibacterial efficacy compared to the BioRoot RCS and the MTA Fillapex $(p<0.001)$. Conclusion: The Total Fill BC Sealer and AH Plus had better antibacterial efficacy than the BioRoot RCS and the MTA Fillapex sealers.
\end{abstract}


bioceramic sealers. They have attracted attention due to their alkaline $\mathrm{pH}$, biocompatibility, bioactivity, non-toxicity, dimensional stability, sealing ability and potential to increace root strenght after obturation (9). Their antimicrobial efficacy has been evaluated in few past in vitro studies using different microbiological methods and obtaining different results (10-12). A recent study by Wang et al. (12) revealed same efficacy of Endosequence BC Sealer as AH Plus against Enterococcus faecalis (E. faecalis) in dentinal tubules after one day, seven days and 30 days of contact time. Another in vitro study reported superiority of the epoxy resin based sealer over a bioceramic sealer (13).

The aim of this study was to evaluate the short-term antimicrobial effect of three bioceramic root canal sealers and epoxy resin based sealer against $72 \mathrm{~h}$ old $E$. faecalis biofilm after 60 minutes of contact time.

\section{Material and methods}

\section{Enterococcus faecalis cultivation}

In this study, we used a wild type strain of $E$. faecalis, which had been isolated from a root canal of the lower first human molar with symptomatic chronic apical periodontitis. The bacteria were grown in brain heart infusion (BHI) broth at $4^{\circ} \mathrm{C}$. Subsequently, few colonies were isolated and grown up on trypticase soy broth (TSB) at $37^{\circ} \mathrm{C}$ overnight. The density of the bacterial suspension was adjusted to $1.0 \mathrm{Mc}$ Farland measured by a densitometer (Densimat, Bio Mérieux, Marcy l'Etoile, France).

For the evaluation of antimicrobial efficacy of bioceramic sealers and epoxy resin based sealer, we used the protocol with filter paper discs described by Barros et al. (14). The $10 \mu \mathrm{L}$ of the E. faecalis suspension was grown on 81 filter paper discs (Whatman GmbH, Dassel, Germany), which were placed on Mitis Salivarius agar plates (Sigma-Aldrich, Taufkirchen, Germany). The paper discs with bacteria were incubated for 48 hours at $37^{\circ} \mathrm{C}$ and $100 \%$ of humidity. The discs were randomly choosen for scanning electron microscopy (SEM) in order to confirme biofilms growth. The selected discs were fixed in 2.5\% glutaraldehyde (Sigma-Aldrich, Taufkirchen, Germany) for $24 \mathrm{~h}$ and then dehydrated in an ascending ethanol solutions $(60 \%, 70 \%, 80 \%$ and $96 \%)$, for 30 minutes in each. After 24 hours of drying on air, the samples were sputter-coated with gold and observed by the SEM (Tescan Vega TS5136LS, Tescan, Brno, Czech Republic).

\section{Placement of sealers on filter discs}

The filter discs with biofilms were divided into four experimental groups ( $\mathrm{n}=17 / \mathrm{each}$ ) according to the tested sealer used and the positive control group $(\mathrm{n}=10)$ :

Group 1: Total Fill Bioceramic Sealer (TotalFill BC Sealer, FKG, Switzerland) i naziva se biokeramičkim punilima. Pozornost su privukli zbog lužnatog $\mathrm{pH}$, biokompatibilnosti, bioaktivnosti, netoksičnosti, dimenzijske stabilnosti, svojstva brtvljenja i potencijala za povećanje čvrstoće korijena nakon punjenja kanala (9). Njihova antimikrobna aktivnost ispitivana je u nekoliko istraživanja in vitro u kojima su se primijenile različite mikrobiološke metode pa su dobiveni i različiti rezultati $(10-12)$. Nedavno istraživanje Wanga i suradnika (12) pokazalo je jednaku učinkovitost Endosequence BC Sealera i AH Plusa, kad je riječ o bakteriji Enterococcus faecalis, u dentinskim tubulusima nakon jedan, sedam i 30 dana kontakta. U drugom, pak, istraživanju in vitro istaknuta je bolja učinkovitost punila proizvedenog na temelju epoksidne smole u usporedbi s biokeramičkim punilom (13).

Cilj ovog istraživanja bio je ispitati kratkoročnu antimikrobnu učinkovitost triju biokeramičkoh punila i punila proizvedenog na temelju epoksidne smole na 72 sata stare biofilmove s $E$. faecalis nakon 60-minutnog kontakta.

\section{Metode}

\section{Kreiranje biofilma s bakterijama Enterococcus faecalis}

U ovom istraživanju koristili smo se divljim sojem bakterije E. faecalis izoliranim iz korijenskog kanala prvoga donjeg molara sa simptomatskim kroničnim apikalnim parodontitisom. Uzgojena je u moždano-srčanom bujonu (engl. brain heart infusion - BHI) na temperaturi od $4{ }^{\circ} \mathrm{C}$. Nekoliko kolonija izolirano je uzgojeno i na mediju triptaza soj agara (engl. trypticase soy broth-TSB) preko noći na temperaturi od $37^{\circ} \mathrm{C}$. Gustoća bakterijske suspenzije podešena je denzitometrom (Densimat, Bio Mérieux, Marcy l'Etoile, Francuska) na 1,0 McFarland.

Korisili smo se protokolom s papirnatim filtar-diskovima opisanim u istraživanju Barrosa i suradnika (14), kako bismo ispitali antibakterijsku učinkovitost biokeramičkih punila i punila prozvedenog na temelju umjetne smole. Količina od $10 \mu \mathrm{L}$ suspenzije E. faecalis postavljena je na 81 papirnati filtar-disk (Whatman GmbH, Dassel, Njemačka) te su zatim položeni na agarnu ploču Mitis Salivarius (Sigma-Aldrich, Taufkirchen, Njemačka). Papirnati diskovi s bakterijama inkubirani su 48 sati na $37^{\circ} \mathrm{C}$, u uvjetima 100 -postotne vlažnosti. Nasumično odabrani diskovi pripremljeni su za promatranje pod pretražnim elektronskim mikroskopom (engl. scanning electron microscopy - SEM) kako bi se potvrdila prisutnost biofilmova.

Diskovi su tijekom 24 sata fiksirani u 2,5-postotnom glutaraldehidu (Sigma-Aldrich, Taufkirchen, Njemačka) te dehidrirani u sve većim koncentracijama otopine etanola (60\%, $70 \%, 80 \%$ i $96 \%) 30$ minuta u svakoj koncentraciji. Nakon 24-satnoga sušenja na zraku, uzorci su napareni zlatom i promatrani mikroskopom (Tescan Vega TS5136LS, Tescan, Brno, Republika Češka).

\section{Postavljanje endodontskih punila na papirnate filtar- diskove}

Papirnati filtar-diskovi s biofilmovima podijeljeni su u sljedeće četiri eksperimentalne skupine ( $\mathrm{n}=17 / \mathrm{each}$ ), ovisno o ispitivanom punilu te u pozitivnu kontrolnu skupinu $(\mathrm{n}=10)$ : 
Group 2: BioRoot Root Canal Sealer (BioRoot RCS, Septodont, Saint Maur Des Fosses, France)

Group 3: MTA Fillapex (Angelus, Londrina, PR, Brasil)

Group 4: Epoxy resin based sealer, AH Plus (Dentsply, Konstanz, Germany)

The tested sealers were prepared according to the manufacturers' instructions. Approximately, $40 \mu \mathrm{L}$ of each freshly prepared sealer, which was measured by a spoon excavator (Premium instruments, New York, USA) of the same volume, was placed on the whole contaminated surface of filter disks. The sealer was spread over each disc using a single use sterile microbiological inoculating loop (Thermo Fisher Scientific, Waltham, MA, USA).

In the positive control group $(\mathrm{n}=10)$, the paper discs with biofilms remained without any sealers. In the negative control group, the sterile discs were not contaminated, but they were covered with the tested sealers ( $\mathrm{n}=$ two samples for each sealer).

\section{Microbiological analysis of antibacterial efficacy}

After 60 minutes of contact time, the sealers were carefully removed from each disc using a sterile Heidelmann instrument (Hu-Friedy Mfg. Co., Frankfurt am Main, Germany). Some minor remnants remained on the surface of few discs. Each disc was placed in a sterile tube containing $1 \mathrm{ml}$ od phosphate-buffered saline (PBS) and slightly agitated for 5 seconds (Vortex mixer X-HD, Sinosource, Guandgong, China) to remove unattached bacterial cells. Then, the discs were transferred to another sterile test tube, which contained $1 \mathrm{ml}$ of PBS, and agitated for 30 seconds. After 8-fold serial dilutions, $10 \mu \mathrm{L}$ of each dilution was grown on Mitis-Salivarius agar plate (Sigma-Aldrich, Taufkirchen, Germany) and incubated for $24 \mathrm{~h}$ on $37^{\circ} \mathrm{C}$ and $100 \%$ humidity. After the incubation period, the colony forming units (CFUs) were counted and transformed into actual count based on the dilution factor.

\section{Statistical analysis}

The obtained data were analysed using the Mann-Whitney $\mathrm{U}$ test. All p-values lower than 0.05 were considered statistically significant. The program IBM SPSS Statistics version 23.0 (www.spss.com) was used.

\section{Results}

The SEM analysis confirmed the presence of biofilms of E. faecalis on filter discs (Figure 1, Figure 2).

All tested materials reduced the number of CFUs significantly compared with the positive controls $(\mathrm{p}<0.001)$ (Table 1). There was no statistically significant difference between the Total Fill BC Sealer and the AH Plus ( $p=0.386)$, nor between the BioRoot RCS and the MTA Fillapex ( $\mathrm{p}=0.931)$ regarding the reduction of the CFUs. The Total Fill BC Sealer and the AH Plus showed greater antibacterial efficacy than the BioRoot RCS and the MTA Fillapex $(\mathrm{p}<0.001)$ (Figure $3)$.
Skupina 1: Total Fill Bioceramic Sealer (TotalFill BC Sealer, FKG, Švicarska)

Skupina 2: BioRoot Root Canal Sealer (BioRoot RCS, Septodont, Saint Maur Des Fosses, Francuska)

Skupina 3: MTA Fillapex (Angelus, Londrina, PR, Brazil)

Skupina 4: punilo proizvedeno na temelju epoksidne smole AH Plus (Dentsply, Konstanz, Njemačka).

Testirani materijali pripremljeni su prema uputama proizvođača. Otprilike $40 \mu \mathrm{L}$ svakog svježe pripremljenog materijala, izmjerenog žličastim ekskavatorom (Premium instruments, New York, SAD) jednakog volumena, postavljeno je na kontaminiranu površinu papirnatoga filtar-diska. Punilo je na njegovu površinu razmazano mikrobiološkom ezom (Thermo Fisher Scientific, Waltham, MA, SAD).

Kao pozitivna kontrolna skupina $(\mathrm{n}=10)$ korišteni su papirnati filtar-diskovi s biofilmovima koji nisu bili prekriveni punilima. Negativna kontrolna skupina bili su sterilni diskovi prekriveni eksperimentalnim punilima $(\mathrm{n}=\mathrm{dva}$ uzorka za svako punilo).

\section{Mikrobiološka analiza antibakterijske učinkovitosti materijala za punjenje}

Nakon 60-minutnog kontakta punila su pažljivo uklonjena sa svakog diska sterilnom Heidelmannovom špatulom (Hu-Friedy Mfg. Co., Frankfurt na Majni, Njemačka). Manji ostatci punila ostali su na nekoliko diskova. Svaki disk stavljen je u sterilnu epruvetu koja je sadržavala $1 \mathrm{ml}$ fosfatom puferirane fiziološke otopine i 5 sekunda je lagano protresen (Vortex mixer X-HD, Sinosource, Guandgong, Kina) kako bi se uklonile neadherirane bakterijske stanice. Zatim su diskovi prebačeni u drugu sterilnu epruvetu koja je sadržavala $1 \mathrm{ml}$ fosfatom puferirane fiziološke otopine i treseni su 30 sekunda. Nakon 8 serijskih razrjeđenja, $10 \mu \mathrm{L}$ suspenzije iz svakog razrjeđenja uzgojeno je na agarnim pločama MitisSalivarius (Sigma-Aldrich, Taufkirchen, Njemačka) i inkubirano 24 sata na $37{ }^{\circ} \mathrm{C}$ u uvjetima 100 -postotne vlažnosti. Nakon inkubacije izbrojen je broj jedinica koje oblikuju kolonije (CFU-s) i izračunat konačni broj kolonija na temelju čimbenika razrjeđenja.

\section{Statistička analiza}

Dobiveni podatci analizirani su Mann-Whitneyjevim U testom. Sve p-vrijednosti niže od 0,05 razmatrane su kao statistički značajne. Za statističku analizu odabran je program IBM SPSS Statistics version 23,0 (www.spss.com).

\section{Rezultati}

Analiza SEM-om potvrdila je prisutnost biofilma s bakterijom E. faecalis na filtru papirnatih diskova (slika 1., slika 2.). Svi ispitivani materijali značajno su smanjili broj bakterija na filtar-diskovima u usporedbi s pozitivnom kontrolnom skupinom $(\mathrm{p}<0,001)$ (tablica 1.). Nije bilo statistički značajne razlike između materijala TotalFill BC i AH Plus $(\mathrm{p}=0,386)$ te između BioRoot RCS-a i MTA Fillapexa ( $p=0,931)$. TotalFill BC i AH Plus bili su antibakterijski učinkovitiji negoli BioRoot RCS i MTA Fillapex (p < 0,001) (slika 3.). 

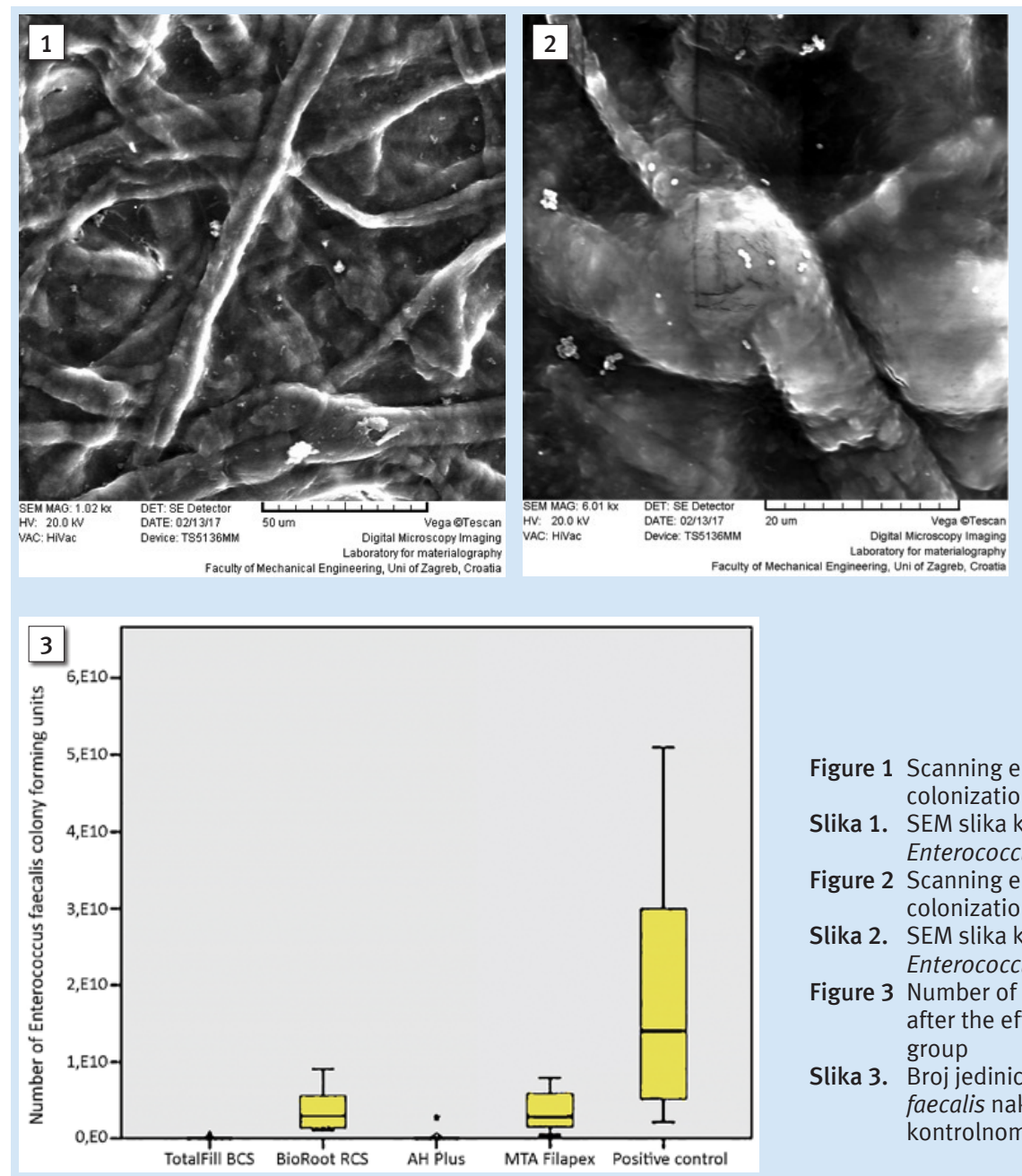

Figure 1 Scanning electron microscopy of Enterococcus faecalis colonization (1002x) of filter paper disk

Slika 1. SEM slika kolonizacije papirnatih filtar-diskova bakterijom Enterococcus faecalis (1002 $\mathrm{x})$

Figure 2 Scanning electron microscopy of Enterococcus faecalis colonization (6000x) of filter paper disk

Slika 2. SEM slika kolonizacije papirnatih filtar-diskova bakterijom Enterococcus faecalis (6000 $\mathrm{x}$ )

Figure 3 Number of Enterococcus faecalis colony forming units after the effect of each sealer and in the positive control group

Slika 3. Broj jedinica koje oblikuju kolonije bakterije Enterococcus faecalis nakon kontakta sa svakim punilom i pozitivnom kontrolnom skupinom

Table 1. Number of CFUs after 60 minutes of exposure to the tested root canal sealers and comparison to the positive control group Tablica 1. Broj CFU-sa nakon 60-minutne izloženosti punilima i usporedba s pozitivnom kontrolnom skupinom

\begin{tabular}{|c|c|c|c|c|c|c|c|c|}
\hline \multirow[b]{2}{*}{ Groups $\bullet$ Skupine } & \multirow[b]{2}{*}{$\begin{array}{l}\text { Mean • } \\
\text { Prosjek }\end{array}$} & \multirow[b]{2}{*}{ SD } & \multirow[b]{2}{*}{ 暜 } & \multirow[b]{2}{*}{ 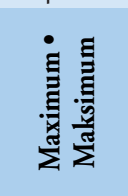 } & \multicolumn{3}{|c|}{ Percentiles $\bullet$ Percentili } & \multirow{2}{*}{$\begin{array}{l}\text { Reduction compared to } \\
\text { positive control } \\
\text { Smanjenje broja u } \\
\text { odnosu prema pozitivnoj } \\
\text { kontroli }\end{array}$} \\
\hline & & & & & $\begin{array}{l}25 \text { th } \cdot 25 \\
\text { sati }\end{array}$ & $\begin{array}{c}\text { 50th } \\
\text { (Median) } \\
\text { 50t sati (sred. } \\
\text { vrijed.) }\end{array}$ & $\begin{array}{c}\text { 75th } \bullet 75 \\
\text { sati }\end{array}$ & \\
\hline TotalFill BCS & $3.72 \mathrm{E}+07$ & $1.20 \mathrm{E}+08$ & $1.00 \mathrm{E}+04$ & $5.00 \mathrm{E}+08$ & $1.00 \mathrm{E}+06$ & $8.00 \mathrm{E}+06$ & $1.00 \mathrm{E}+07$ & $99.94 \%$ \\
\hline BioRoot RCS & $3.58 \mathrm{E}+09$ & $2.56 \mathrm{E}+09$ & $1.00 \mathrm{E}+09$ & $9.00 \mathrm{E}+09$ & $1.40 \mathrm{E}+09$ & $2.90 \mathrm{E}+09$ & $6.00 \mathrm{E}+09$ & $79.29 \%$ \\
\hline AH Plus & $1.78 \mathrm{E}+08$ & $6.51 \mathrm{E}+08$ & $1.00 \mathrm{E}+05$ & $2.70 \mathrm{E}+09$ & $1.00 \mathrm{E}+06$ & $1.00 \mathrm{E}+07$ & $4.75 \mathrm{E}+07$ & $99.93 \%$ \\
\hline MTA Filapex & $3.51 \mathrm{E}+09$ & $2.50 \mathrm{E}+09$ & $4.00 \mathrm{E}+08$ & $7.90 \mathrm{E}+09$ & $1.45 \mathrm{E}+09$ & $2.80 \mathrm{E}+09$ & $6.05 \mathrm{E}+09$ & $80.00 \%$ \\
\hline $\begin{array}{l}\text { Positive control } \bullet \\
\text { Pozitivna kontrola }\end{array}$ & $2.44 \mathrm{E}+10$ & $2.75 \mathrm{E}+10$ & $2.10 \mathrm{E}+09$ & $9.00 \mathrm{E}+10$ & $4.75 \mathrm{E}+09$ & $1.40 \mathrm{E}+10$ & $3.53 \mathrm{E}+10$ & \\
\hline
\end{tabular}

\section{Discussion}

Although all tested sealers showed significantly lower nuber of CFUs, there was no complete eradication of bacteria in any group. Firstly, these results can be explained due to the source of bacteria. In this study, wild-type strain of E. faecalis was used. Wild-type strains are less susceptible to sealers compared to most commonly used ATCC strain of E. Faecalis, and they have been recommended for the evaluation of antimicrobial efficacy of sealers (14). Also, E. faecalis has a significant role in etiology of persistent periradic-

\section{Rasprava}

Iako su svi testirani materijali pokazali da smanjuju broj jedinica koje formiraju kolonije (CFU-s), ni u jednoj skupini bakterije nisu potpuno eliminirane. Takvi se rezultati uglavnom vežu uz izvor bakterija. U ovom istraživanju korišten je divlji soj E. faecalis. Naime, divlji sojevi manje su osjetljivi u usporedbi $s$ najččšce korištenim ATCC sojem bakterije E. faecalis na djelovanje punila te se preporučuju za ispitivanje njihove antimikrobne učinkovitosti (14). E. faecalis također je također važan u etiologiji perzistirajućih periradikular- 
ular lesions (15) due to its virulence factors and ability to survive the conventional chemo-mechanical root canal procedures (16).

Secondly, the type of bacteria can affect antibacterial efficacy of sealers. Most previous studies evaluated the antibacterial efficacy of root canal sealers against planktonic bacteria $(7,13,17)$. However, since planktonic bacteria do not represent a real clinical situation in infected root canals, the use of older bacterial biofilms which express greater resistance has been recommended $(12,18,19)$. In this study, we used 48 hours old bacterial biofilm in a microbiological protocol described by Barros et al. (14). Therefore, the recommendation for further studies is to investigate the antibacterial efficacy of sealers on older biofilms.

Our finding of no complete eradication in all groups is cosistent with few previous studies $(20,21)$. On the contrary, Zhang et al. (7) reported complete eradication of E. faecalis after application of both, the bioceramic root canal sealer (iRoot SP Sealer) (for 2 minutes) and the AH Plus (for 5 to 20 minutes) sealer. This result could be related to the planktonic species of bacteria used in suspension. These bacteria are more susceptible than biofilms (22).

The results of this study also showed similar antibacterial activity of the TotalFill BC Sealer and the epoxy resin based AH Plus against $E$. faecalis biofilms (eradication of more then 99.9\%) after contact time of 60 minutes. The same conclusions have been reached in a recent study by Wang et al (12), in which no difference between the bioceramic sealer (Endosequence BC Sealer) and the AH Plus was found even after longer contact time of one day, seven days and 30 days using confocal microscopy evaluation. The antibacterial efficacy of bioceramic sealers is considered to be related to the release of $\mathrm{Ca}^{2+}$ ions and high $\mathrm{pH}(7,17,22)$. In another study by Nirupama et al (13), the AH Plus and the bioceramic iRoot SP sealers showed statistically significant antibacterial efficacy against $E$. faecalis. However, the AH Plus presented longer antibacterial effect (18 hours), probably due to its releasing of bisphenol-A-diglycidyl ether during polymerization (23). In this study, we evaluated the antimicrobial effect of the sealers only within 60 minutes of application since the direct contact test (DCT) on filter paper discs is solely intended for testing the short-term antimicrobial effect of the sealers (24). Namely, the DCT studies, where dentin is not preset, have shown that the sealers lose their antibacterial effect within a few hours or days from mixing $(7,24)$. Also, durations shorter than 60 minutes proved to be too short to affect resisting bacteria such as $E$. faecalis (25).

An interesting finding of this study is superior results of the Total Fill BC Sealer over the BioRoot RCS since both materials are bioceramics and of similar composition. The BioRoot RCS is the newest two-component root canal sealer. The powder component is composed of tricalcium silicate, zirconium dioxide and povidone, and the liquid is composed of water, calcium chloride and polycarboxylate. There have been only few studies published so far on its antibacterial activity $(25,26)$. Poggio et al. (25) reported lower antibacterial activity of the BioRoot RCS compared with epoxy resin sealers against $18 \mathrm{~h}$ old $E$. faecalis, which was explained due to its nih lezija (15) jer sadržava čimbenike virulencije i svojstvo da preživi konvencionalnu kemomehaničku obradu korijenskih kanala (16).

Drugo, antibakterijska učinkovitost punila može ovisiti o starosnoj skupini bakterija. U većini dosadašnjih istraživanja ispitivana je antibakterijska učinkovitost punila na planktonskim bakterijskim stanicama $(7,13,17)$. No te stanice ne pokazuju stvarnu situaciju u inficiranim korijenskim kanalima i zato se preporučuje korištenje starijih bakterijskih biofilmova koji su otporniji na antimikrobna sredstva $(12,18,19)$. U ovom istraživanju koristili smo se 48 sati starim biofilmovima i mikrobiološkim protokolom opisanim u istraživanju Barrosa i suradnika (14). Preporuka je da se za daljnja istraživanja antibakterijske učinkovitosti upotrebljavaju punila starijih biofilmova.

Rezultati našeg istraživanja pokazuju nepotpunu eliminaciju bakterija u svim skupinama, što se može usporediti $s$ dosadašnjim studijama $(20,21)$. Suprotno su pokazali Zhang i suradnici (7) u čijem su istraživanju biokeramički materijal Root SP Sealer (unutar 2 minute) i AH Plus (unutar 5 do 20 minuta) potpuno eliminitrali bakteriju E. faecalis. Takav se rezultat može objasniti činjenicom da su planktonske stanice osjetljivije od biofilmova na djelovanje antimikrobnih sredstava (22).

Naši rezultati također su pokazali sličnu antibakterijsku učinkovitost TotalFill BC punila i AH Plusa, materijala proizvedenog na temelju umjetne smole, kad je riječ o biofilmovima $s$. faecalis (eliminacija 99,9 \%) nakon 60-minutnog kontakta. Isto su zaključili i Wang i suradnici (13) u istraživanju u kojemu su s pomoću konfokalne laserske mikroskopije pokazali da nema razlike između biokeramičkog punila (Endosequence BC punila) i AH Plusa nakon duljih kontakata (jedan, sedam i 30 dana). Smatra se da je antibakterijska učinkovitost biokeramičkih punila povezana $s$ otpuštanjem $\mathrm{Ca}^{2+}$ iona i visokih $\mathrm{pH}$ punila $(7,17,22)$. $\mathrm{U}$ istraživanju Nirupame i suradnika (13), biokeramički materijali AH Plus i Root SP pokazali su značajnu antibakterijsku učinkovitost kad je riječ o E. faecalis. No AH Plus je bio dulje učinkovit (18 sati), vjerojatno zbog otpuštanja bisfenol-A-diglicidilnog etera tijekom polimerizacije (23). U ovom istraživanju ispitivali smo antimikrobnu učinkovitost punila unutar 60 minuta od postavljanja materijala, a koristili smo se direktnim kontaktnim testom (engl. direct contact test - DCT) zato što se DCT upotrebljava samo za ispitivanje kratkoročnog antimikrobnog učinka punila (24).

Naime, $\mathrm{u}$ istraživanjima u kojima se primijenio DCT, a nisu imala dentin kao podlogu, istaknuto je da punila gube antibakterijski učinak za nekoliko sati ili dana od miješanja ( 7 , 24). I vrijeme kraće od 60 minuta pokazalo se prekratkim za početak djelovanja punila na bakterije poput E. faecalis (25).

Zanimljiv rezultat ovog istraživanja su superiorni rezultati dobiveni za Totalfill BC Sealera u usporedbi s BioRoot RCSom, zato što su oba materijala biokeramička i imaju sličan sastav. BioRoot RCS najnovije je dvokomponentno punilo. Prah se sastoji od trikalcijeva silikata, cirkonijeva dioksida i povidona, a tekućina od vode, kalcijeva klorida i polikarboksilata. Dosad je objavljeno nekoliko istraživanja o njegovu antibakterijskom djelovanju $(25,26)$. Poggio i suradnici $(25)$ 
shorter working (minimum $10 \mathrm{~min}$ ) and setting time (maximum 4 h) $(26,27)$.

Another reason could be related to smaller homogeneity of the BioRoot RCS after hand mixing when compared with the "premixing" bioceramic sealers. In the most recent study of Arias-Moliz et al. (26), the BioRoot RCS showed better intratubular antibacterial efficacy compared with the MTA Fillapex and the AH Plus.

Different results of the same materials in the above mentioned studies could be explained due to different microbial tests used $(10,25)$. The most commonly used microbial tests in this kind of studies are DCT and agar diffusion test (ADT) $(17,25,28,29)$. ADT has been suitable for soluble materials but due to its limitations (dependence on diffusion and physical properties of tested materials, does not distinguish bacteriostatic or bactericidal effect of the material) (29) this test is no longer recommended (7). DCT is a quantitative and reproducible method to simulate the contact of microorganisms with endodontic sealers, providing information about bactericidal effect (7), thus being more reliable and relevant $(9,14)$.

In conclusion, Total Fill BCS and AH Plus presented similar antibacterial efficacy against $E$. faeaclis, which was superior compared to BioRoot RCS and MTA Fillapex. opisali su slabiju antibakterijsku učinkovitost BioRoot RCS a u usporedbi s punilom na bazi epoksidne smole na 18 sati stare biofilmove s bakterijom E. faecalis, što se tumači kraćim radnim vremenom (minimum 10 minuta) i vremenom stvrdnjavanja (maksimalno 4 sata) $(26,27)$. Drugi razlog mogao bi biti povezan $s$ manjom homogenosti tog punila u usporedbi s onima već tvornički pripremljenima (engl. premixing. U najnovijem istraživanju Arias-Moliza i suradnika (26), BioRoot RCS postigao je bolju intratubularnu antibakterijsku učinkovitost u usporedbi s MTA Fillapexom i AH Plusom.

Različiti rezultati za iste materijale u navedenim istraživanjima mogu se objasniti korištenjem različitih mikrobioloških testova $(10,25)$. Najčešće korišteni testovi u takvoj vrsti istraživanja su DCT i agarni difuzijski test (ADT) $(17,25$, $28,29)$. ADT je odgovarajući test za ispitivanje topljivih materijala, ali zbog njegova ograničenja (ovisnost o difuzijskim i fizikalnim svojstvima ispitivanih materijala) ne može se ustanoviti je li riječ o bakteriostatskom ili baktericidnom učinku materijala (29) te se više ne preporučuje (7).

DCT je kvantitivna i ponovljiva metoda za oponašanje kontakta mikroorganizama $s$ endodontskim materijalima i daje informaciju o baktericidnom učinku (7) pa je zato pouzdanija i relevantnija metoda $(9,14)$.

Zaključno, TotalFill BC Sealer i AH Plus pokazali su da slično antibakterijski djeluju na bakteriju $E$. faeaclis, i to bolje u usporedbi s BioRoot RCS-om i MTA Fillapexom.

\section{Sukob Interesa}

Autori nisu bili u sukobu interesa.

None declared

Zaprimljen: 10. rujna 2019.

Prihvaćen: 3. veljače 2020.

Adresa za dopisivanje

Marija Šimundić Munitić, dr. dent. med.

Stomatološka poliklinika Split

Odjel endodoncije i restaurativne stomatologije

A.G. Matoša 2, 21000 Split, Hrvatska te: +38521386126

mob: +385989048033

msimundic4@gmail.com

Ključne riječi

antibakterijska sredstva; Enterococcus faecalis; materijali za punjenje korijenskog kanala; organski preinačene keramike

\section{References}

1. Chugal NM, Clive JM, Spangberg LS. Endodontic infection: some biologic and treatment factors associated with outcome. Oral Surg Oral Med Oral Pathol Oral Radiol Endod. 2003 Jul;96(1):8190.

2. Bystrom A, Sundquist G. The antibacterial action of sodium hypochlorite and EDTA in 60 cases of endodontic therapy. Int Endod J. 1985 Jan;18(1):35-40.

3. Siqueira JF Jr., Magalhaes KM, Rocas IN. Bacterial reduction in infected root canals treated with $2.5 \% \mathrm{NaOCl}$ as an irrigant and calciumhydroxide/ camphorated paramonochlorophenol paste as an intracanal dressing. J Endod. 2007 Jun;33(6):667-72.

4. Nair PN, Henry S, Cano V. Microbial status of apical root canal system of human mandibular first molars with primary apical peri- odontitis after „one-visit“ endodontic treatment. Oral Surg Oral Med Oral Pathol Oral Radiol Endod. 2005 Feb;99(2):231-52.

5. Rocas IN, Lima KC, Siqueira JF, Jr. Reduction in bacterial counts in infected root canals after rotary and hand nickel-titanium instrumentation- a clinical study. Int Endod J. 2013 Jul;46(7):681-7.

6. Toljan I, Bago I, Anic I. Eradicationof intracanal Enterococcus faecalis biofilm by passive ultrasonic irrigation and RinsEndo system. Acta Stomatol Croat. 2016 Mar;50(1):14-22.

7. Ozbay G, Kitiki B, Peker S, Kargul B. Apical Sealing Ability of a Novel Material: Analysis by Fluid Filtration Technique. Acta Stomatol Croat. 2014 Jun;48(2):132-9.

8. Zhang H, Shen Y, Ruse ND. Antibacterial activity of endodontic sealers by modified direct contact test against Enterococcus faecalis. J Endod. 2009 Jul;35(7):1051-5. 
9. Nawal RR, Parande M, Sehgal R. A comparative evaluation of antimicrobial efficacy and flow properties for Epiphany, Guttaflow and AH-Plus sealer. Int Endod J. 2011 Apr;44(4):307-13.

10. Wang Z. Bioceramic materials in endodontics. Endodontic topics. 2015;32:3-30.

11. Candeiro GT, Correia FC, Duarte MA. Evaluation of radiopacity, $\mathrm{pH}$, release of calcium ions and flow of a bioceramic root canal sealer. J Endod. 2012 Jun;38(6):842-5.

12. Khalil I, Naaman A, Camilleri J. Properties of Tricalcium silicate sealers. J Endod. 2016 Oct;42(10):1529-35

13. Wang Z, Shen Y, Haapasalo M. Dentin extends the antibacteria effect of endodontic sealers against Enterococcus faecalis biofilms. J Endod. 2014 Apr;40(4):505-8.

14. Nirupama DN, Nainan MT, Ramaswamy R. In vitro evaluation of the antimicrobial efficacy of four endodontic biomaterials against Enterococcus faecalis, Candida albicans and Styphylococcus aureus. Int J Biomater. 2014;2014:383756.

15. Barros J, Silva MG, Rocas IN. Antibiofilm effects of endodontic sealers containing quaternary ammonium polyethylenimine nanoparticles. J Endod. 2014 Aug;40(8):1167-71.

16. Siqueira JF, Jr., Rocas IN. Polymerase chain reaction-based analysis of microorganisms associated with failed endodontic treatment. Oral Surg Oral Med Oral Pathol Oral Radiol Endod. 2004 Jan;97(1):85-94.

17. Love RM. Enterococcus faecalis- a mechanism for its role in endodontic failure. Int Endod J. 2001 Jul;34(5):399-405.

18. Candeiro GTM, Moura-Neto C, D’Almeida-Couto RS. Cytotoxicity, genotoxixity and antibacterial effectiveness of a bioceramic endodontic sealer. Int Endod J. 2016 Sep;49(9):858864.

19. Rezende GC, Massunari L, Queiroz IO. Antimicrobial action of calcium hydroxide-based endodontic sealers after setting against E.faecalis biofilm. Braz Oral Res. 2016;30.

20. Stojicic S, Shen Y, Haapasalo M. Effect of the source of biofilm bacteria, level of biofilm maturation and type of disinfecting agent on the susceptibility of biofilm bacteria to antibacterial agents. J Endod. 2013 Apr;39(4):473-7.

21. Bailon- Sanchez ME, Baca P, Ruiz- Linares M, Ferrer-Luque CM. Antibacterial and anti- biofilm activity on $\mathrm{AH}$ plus with chlorhexidine and cetrimide. J Endod. 2014 Jul;40(7):977-81.

22. Du T, Wang Z, Shen Y, Ma J, Cao Y, Haapasalo M. Combined antibacterial effect of sodium hypochlorite and root canal sealers against Enterococcus faecalis biofilm sin dentin canals. J Endod. 2015 Aug;41(8):1294-8.

23. Borges RP, Sousa-Neto MD, Versiani MA, Rached-Júnior FA, De Deus G, Miranda CE. Changes in the surface of four calcium silicate- containing endodontic materials and an epoxy resin-based sealer after a solubility test. Int Endod J. 2012 May;45(5):419-28.

24. Slutzky- Goldberg I, Slutzky H, Solomonov M, Moshonov J, Weiss El, Matalon S. Antibacterial properties of four endodontic sealers. J Endod. 2008 Jun;34(6):735-8.

25. Kayaoglu G, Erten H, Alacam T. Short- term antibacterial activi ty of root canal sealers towards Enterococcus faelis. Int Endod J. 2005;38(7):483-8

26. Poggio C, Trovati F, Ceci M, Colombo M1, Pietrocola G. Antibacterial activityof different root canal sealers against Enterococcus faecalis. J Clin Exp Dent. 2017 Jun 1;9(6):e743-e748.

27. Arias- Moliz MT, Camilleri J. The effectof the final irrigant on the antimicrobial activity of root canal sealers. J Dent. 2016 Sep;52:30-6.

28. Prullage RK, Urban K, Schafer E, Dammaschke. Material properties of a tricalcium silicate- containing, a mineral trioxide aggre gate- containing and epoxy resin-based root canal sealer. J Endod. 2016 Dec;42(12):1784-1788.

29. Morgental RD, Vier-Pelisser FV, Oliveira SD, Antunes FC, Cogo DM, Kopper PM. Antibacterial activity of two MTA-based root canal sealer. Int Endod J. 2011 Dec;44(12):1128-33.

30. Cobankara FK, Altinoz HC, Ergani O, Kav K, Belli S.. In vitro antibacterial activities of root-canal sealers by using two different methods. J Endod. 2004 Jan;30(1):57-60. 